$6-2008$

\title{
Development Of Master's Programs In Sustainable Engineering
}

Brian K. Thorn

Andres L. Carrano

Follow this and additional works at: https://digitalcommons.fairfield.edu/engineering-facultypubs (C) 2008 American Society for Engineering Education

\section{Peer Reviewed}

\section{Published Citation}

Thorn, B., \& Carrano, A. (2008, June), Development Of Master's Programs In Sustainable Engineering Paper presented at 2008 Annual Conference \& Exposition, Pittsburgh, Pennsylvania. 10.18260/1-2--3736

This item has been accepted for inclusion in DigitalCommons@Fairfield by an authorized administrator of DigitalCommons@Fairfield. It is brought to you by DigitalCommons@Fairfield with permission from the rightsholder(s) and is protected by copyright and/or related rights. You are free to use this item in any way that is permitted by the copyright and related rights legislation that applies to your use. For other uses, you need to obtain permission from the rights-holder(s) directly, unless additional rights are indicated by a Creative Commons license in the record and/or on the work itself. For more information, please contact digitalcommons@fairfield.edu. 


\section{AC 2008-1217: DEVELOPMENT OF MASTER'S PROGRAMS IN SUSTAINABLE ENGINEERING}

\section{Brian Thorn, Rochester Institute of Technology}

BRIAN K. THORN is an associate professor in the Industrial and Systems Engineering Department at the Rochester Institute of Technology in New York. He received a B.S. in Industrial Engineering from the Rochester Institute of Technology, an M.S. and Ph.D. from the Georgia Institute of Technology. His research interests include sustainable product and process design, life cycle analysis and applied statistical methods.

\section{Andres Carrano, Rochester Institute of Technology}

ANDRES L. CARRANO is an associate professor in the Industrial and Systems Engineering Department at the Rochester Institute of Technology in New York. He received a B.S. in Industrial Engineering from the Catholic University in Venezuela, an M.S. and Ph.D. from North Carolina State University. His research interests include surface metrology, sustainable product and process design as well as life cycle analysis. 


\title{
Development of Master's Programs in Sustainable Engineering at the Rochester Institute of Technology
}

\begin{abstract}
During the 2006-2007 academic year, a team of faculty from the Kate Gleason College of Engineering developed a proposal for a pair of Master's programs (a Master of Science program and a Master of Engineering proposal) in the field of Sustainable Engineering. Sustainable Engineering has been described as "engineering for human development that meets the needs of the present without compromising the ability of future generations to meet their own needs" [3]. Both programs are multidisciplinary in nature and include coursework from the disciplines of Industrial and Systems Engineering, Mechanical Engineering, Civil Engineering Technology, and Public Policy. The programs offer students the flexibility to develop 'tracks' in their program of study which would permit deeper immersion in domains such as renewable energy systems, systems modeling and analysis, product design, etc. Student interest in the programs has been very favorable. This paper describes the context at RIT from which the idea for these programs arose, the program development process that was followed, and the structure of the two programs.
\end{abstract}

\section{Background}

Efforts to reform engineering education over the past two decades have met with limited success. Although some engineering programs have effectively addressed a new vision for engineering pedagogy, the National Academy of Sciences [9] and the National Research Council $[10,11]$ have identified several problematic attributes in engineering education. In particular, engineering programs have been criticized for their inability to effectively integrate multiple engineering and non-engineering disciplines in solving today's complex science and technology problems.

Nowhere is the appreciation of the technical and non-technical aspects of the engineering field more appropriate than in problem domains related to "sustainability". Interest in sustainability and related issues continues to grow nationally as well as internationally. A sustainable economy is one that can meet the needs of the present without compromising the ability of future generations to meet their own needs [13]. Moving an economy toward the goal of sustainability presents myriad challenges for all professions, especially business and engineering. As we move forward in the $21^{\text {st }}$ century, the problems associated with delivering society's goods and services using traditional, non-sustainable practices will become more apparent, and the value of more environmentally and socially responsible approaches to meeting society's needs will become increasingly evident. Engineers and managers must be equipped to become environmental leaders and decision makers. 
Toward this end, college curricula will need to change in order to equip engineers and business leaders with the tools they will need to meet the challenge of delivering goods and services through sustainable means. This notion is reinforced by the inclusion of knowledge about sustainability as one of the core criteria that engineering programs must demonstrate their students attain in order to earn accreditation by the Accreditation Board for Engineering and Technology.

Engineering programs must demonstrate that their students attain... an ability to design a system, component, or process to meet desired needs within realistic constraints such as economic, environmental, social, political, ethical, health and safety, manufacturability and sustainability [1]

The Kate Gleason College of Engineering (KGCOE) at the Rochester Institute of Technology (RIT) has about 700 students enrolled in its five engineering programs. In recent years the college has seen significant innovation in the areas of sustainability and sustainable engineering. Some of these innovations have been motivated by faculty involved in this area, others by students interested in working in the area of sustainability. Many of the innovations are curricular in nature while others evolved from the convergence of volunteerism and professional development. This paper describes the forces that motivated the development of two Master's level programs in Sustainable Engineering, and the interdisciplinary curricula that comprises them.

\section{Early Graduate Student Work}

Some of the early sustainability oriented work in the KGCOE was undertaken by graduate students in the Mechanical Engineering (ME) and the Industrial and Systems Engineering (ISE) departments working on their MS theses. Typically, these thesis projects involved the application of traditional optimization or analysis techniques to problem domains with environmental themes. Early examples include

- Using Product Architecture to Maximize Environmental Performance [12], and

- Utilization of Statistical Tools to Identify Assignable Causes of Variability and Model Performance of a Wet Electrostatic Precipitator (WESP) 514]

\section{Course Development}

Given the level of interest being demonstrated by students, it became clear to the faculty and administration of KGCOE that the development of formal engineering courses dealing with sustainability themes would be useful. The first such courses developed in KGCOE were "Fuel Cell Technology" (offered by the ME department), "Fundamentals of Sustainable Engineering", and "Lifecycle Costing and Assessment" (offered by ISE).

The Fuel Cell Technology course (introduced in 2001) teaches fuel cell basics and operating principles for the various fuel cell technologies (polymer electrolyte membrane, phosphoric acid, molten carbonate, and solid oxide). The various technologies are reviewed with respect to thermal system design and analysis issues, limitations, cost effectiveness and efficiency. 
Fundamentals of Sustainable Engineering (introduced in 2002) is a survey course that reviews the product lifecycle from various perspectives and highlights the leverage over material, process, and environmental impacts available at the design phase. The course introduces and evaluates tools and strategies for reducing the environmental impacts associated with the sourcing, manufacture, use, and retirement of products. Students in this course are required to complete two team based projects that require independent research and presentation of the results to the class.

The Lifecycle Costing and Assessment course (first taught in 2004) introduces students to the challenges posed when trying to determine the total lifecycle costs associated with a product or a process design. Various costing models and their inherent assumptions are reviewed and critiqued, and the inability of traditional costing models to account for important environmental and social externalities is highlighted. The Lifecycle Assessment approach for quantifying environmental and social externalities is introduced, and three specific LCA techniques (Streamlined Lifecycle Assessment, Economic Input/Output LCA, and Process/Inventory Based LCA) are covered. Students in this course must perform each type of LCA on a specific product and report their findings to the class.

These courses proved to be popular electives, and are currently offered once each academic year.

In addition to being included in these new course offerings, sustainability themes have been integrated into the capstone design experience that is required of all engineering programs receiving accreditation from the Accreditation Board for Engineering and Technology (ABET). In the KGCOE, the multidisciplinary senior design experience spans 2 quarters (20 weeks) for most students, and 3 quarters (30 weeks) for those who wish to be project leaders. Multidisciplinary teams of 4 to 8 students work on open ended design projects and move through a phases and gates process to generate the deliverables that they define. Initially, in 2004 , only two of the 50 or so projects directly addressed problems with a sustainability theme. However, these projects and others that followed proved to be very popular among senior engineering students. Demand for projects has been so strong that currently the Multidisciplinary Senior Design program lists a "Sustainable Products, Systems, and Technologies" track as one of six available project focus areas. Four project families (Sustainable Technologies for Developing Nations, Sustainable Technologies for the RIT Campus, Sustainable Technologies for the Global Marketplace, and Next Generation Thermo-Electric Systems) have been opened within this track (more than any other track). More detailed information can be found at the following website: http://edge.rit.edu/content/DPM/public/Proposed\%20Projects

\section{Later Graduate Student Work}

Many of the students who were exposed to sustainability topics through the courses and projects described above chose to do Master's work with sustainability themes. In many cases the exposure to the courses described above enabled the students to engage much more sophisticated problems than they could have addressed without this preparation. Examples of later Master's thesis titles (some are ongoing) include:

- Large Scale Proactive Approach to Reducing Energy Consumption of city Buildings in Rochester [6] 
- Remanufacturing Alternatives to Reduce the Magnitude of Environmental Impacts Using TRACI [8]

- Exergetic Based Leak Detection and Diagnosis Methodology for Automotive Carbon Dioxide Air Conditioning Systems [2]

- Making Sustainable and Environmental Improvements through focused Factories [7]

- Exergetic Analysis of Energy Intensive Systems within Buildings [5]

- Economic and Environmental Impacts of Waste Cooking Oil Collection for Use as Biodiesel [15]

- Modeling Environmental Impact of Demand Variability upon Supply Chains in the beverage Industry [4]

\section{A Student Professional Society}

By the Fall of 2005, student interest in sustainability in the KGCOE had reached the point where it appeared that there was a critical mass large enough to support a student professional society committed to the goals of sustainability. A team of students (graduate and undergraduate) took on the responsibility of developing a charter for and founding the RIT student chapter of Engineers for a Sustainable World (ESW). The stated mission of the chapter at RIT is "To involve the students in hands-on experience and projects that will ultimately improve sustainability worldwide."

The ESW chapter has taken on a number of initiatives, on campus and off. Many of these projects could be described as active learning experiences and service learning opportunities. For example, as part of their philanthropic mission, the ESW chapter has partnered with a homeless shelter in downtown Rochester. Each week a team of students volunteers to work at the shelter sorting food, serving meals, or performing needed repairs. Other projects attempt to further awareness of sustainability on campus. For instance, the chapter has hosted two UV Tube workshops where students learn of the problems associated with lack of potable water in developing nations, and actually fabricate a working ultraviolet water sterilizer. ESW also arranges tours (open to the campus community) of recycling centers, landfill operations, environmentally responsible manufacturers, etc. as well as book drives for donations and electronic recycling efforts. The group has also undertaken efforts to improve the environmental performance of the RIT campus. Projects of this sort include an energy audit of student housing, and the generation of a proposal requesting state funding to support the replacement of incandescent lighting systems with fluorescent or LED technology.

\section{Development of a Program Minor}

The two factors of student interest in sustainability and course development in this area seem to be part of a positive reinforcement loop: as more students become interested in sustainability, they would like to take more courses with those themes, and, as more courses of this type are offered, more students become interested in the area. This cycle, in part, led to the development of a multidisciplinary minor in Sustainable Product Development.

At RIT, a program minor consists of 5 courses ( 20 credit hours) in a related area. The Sustainable Product Development minor is aimed at students interested in exploring issues associated with developing and delivering sustainable product systems. Courses in the minor enhance understanding of the three dimensions of sustainability (economic, ethical, environmental), develop awareness of the need for more sustainable approaches to product 
development, and explore strategies for developing and delivering sustainable product systems.

The minor is administered through the ISE department, but it is structured to guarantee a truly multidisciplinary experience. There are three required core courses that are offered by the ISE department (Engineering Economics, Fundamentals of Sustainable Engineering, and LifeCycle Costing and Assessment). Of the two remaining courses, one must be taken from a list of available "Social Context Electives" and the other must be taken from the list of available "Technical Electives". The Social Context Electives feature courses from the Management Department in the College of Business and courses from the Department of Public Policy in the College of Liberal Arts. The Technical Electives consist of sustainability themed courses from the KGCOE and appropriate courses from the Civil Engineering Technology, Environmental Management and Safety Department in the College of Applied Science and Technology. More details are available at http://www.rit.edu/ 633www/minors/SPD/index.html. During its first year, 6 undergraduate students were enrolled in the minor. This is more than participate in either of the other two minors offered by the ISE department, and is considered quite remarkable, given the newness of the minor and the lack of publicity promoting it.

It should be emphasized here that the minor in Sustainable Product Development was designed to be available to non-engineering students as well as those enrolled in engineering programs. So far, in addition to engineering students, students from business programs and from the Industrial Design program have participated in the courses in the minor. We expect non-engineering participation to grow as the minor matures and is better publicized.

\section{Development of Graduate Programs}

Given the continued student interest in sustainability themed engineering education and continued course development to support those interests, the leadership of the KGCOE determined that it would be appropriate to introduce graduate level programs in this area.

A core team of faculty was assembled with representation from the ME department and the ISE department. These departments would be responsible for delivering the majority of the program content.

Two graduate programs were proposed, a Master of Science program (which culminates with the completion of a Master thesis) and a Master of Engineering degree program (which does not require the thesis). Both programs are titled "Sustainable Engineering". The objectives of the programs are to equip engineers with the tools they will need to meet the challenges associated with delivering goods, energy and services through sustainable means. These programs will deliver education on sustainable design methods related to the design of products, processes, and energy related systems as well as end of life management decision tools and technologies.

The structure of the M.Eng. program is shown in Figure 1, and that of the M.S. program in Figure 2. 


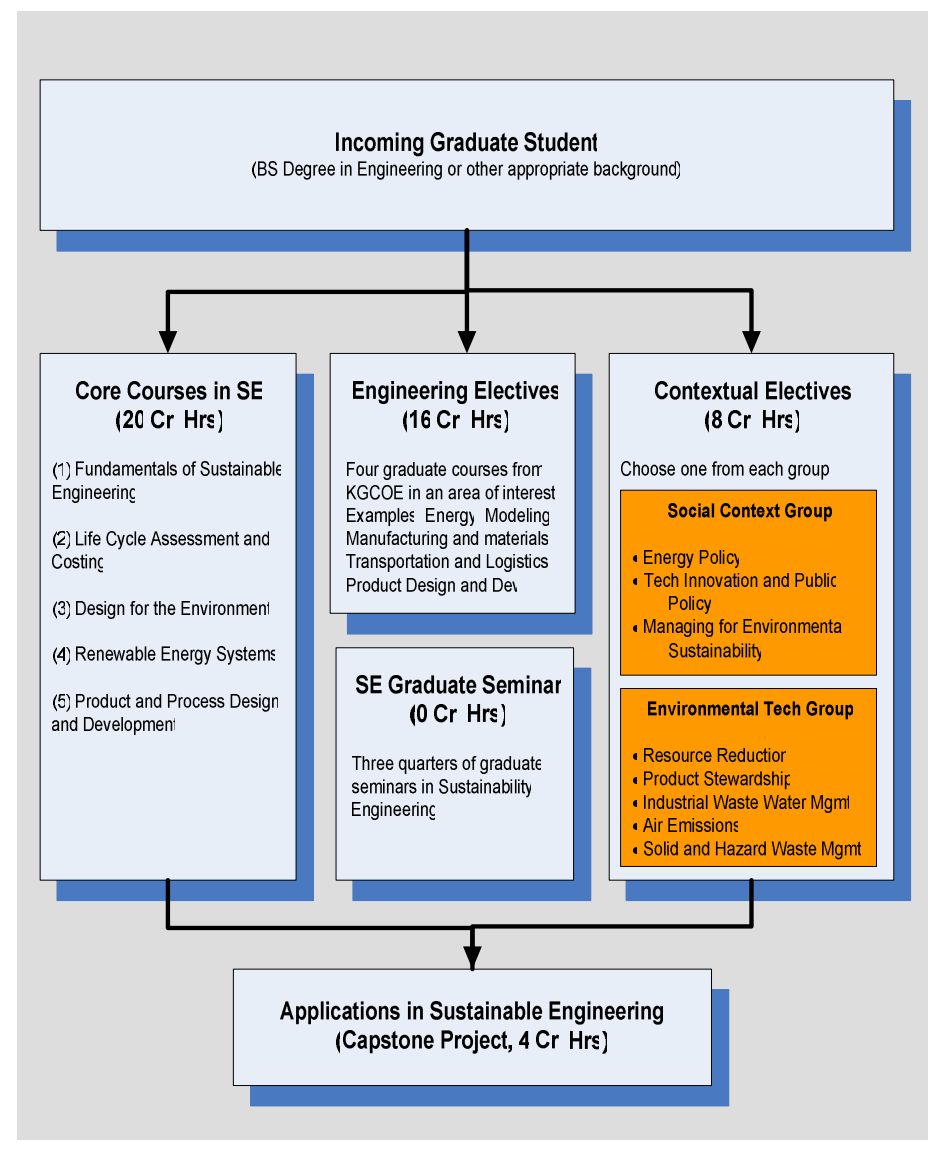

Fig. 1. Curricular Structure of the Master of Engineering Program in Sustainable Engineering 


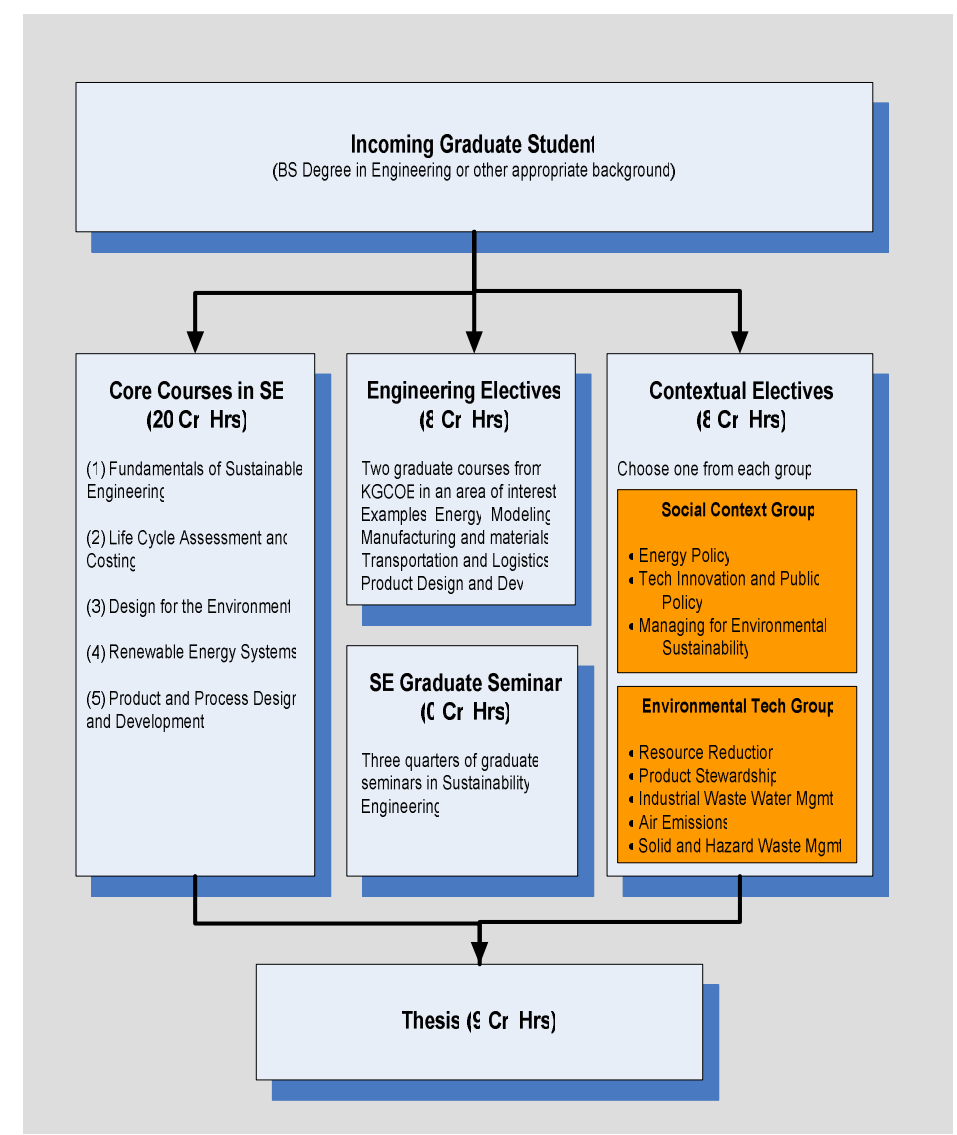

Fig. 2. Curricular Structure of the Master of

Science Program in Sustainable Engineering

Both programs target engineering or other technically trained students with Bachelor of Science Degrees. Both programs rely on a combination of a set of core courses, a set of technical electives from within the KGCOE, and a set of contextual electives taken from outside the KGCOE. The elements of the programs are described below.

\subsection{Core Courses}

The core courses are intended to provide students with the foundations of sustainable engineering. These courses are hosted by the Departments of Industrial and Systems Engineering and Mechanical Engineering (KGCOE).

\subsection{Engineering Electives}

This set of courses is intended to support the student's main areas of interest or research, as driven by the capstone or thesis. These consist of either four courses ( 16 credit hours for M.Eng. students) or two courses ( 8 credit hours for M.S. students) that will be chosen in conjunction with the advisor from course offerings in any concentration area within KGCOE. Some example concentration areas include (but are not limited to) the following: Energy, Modeling, Manufacturing and Materials, Transportation and Logistics, and Product Development. 


\subsection{Contextual Electives}

This course set is intended to complement the student's preparation with knowledge in areas that may lie outside the direct scope of engineering. One course ( 4 credit hours) is required in the Social Context group, which will be delivered by the Department of Public Policy or the College of Business, while the other course (4 credit hours) is required in Environmental Technology, to be delivered by the Department of Civil Engineering Technology, Environmental Management and Safety. Currently, the social context group includes course offerings such as "Energy Policy", "Technological Innovation and Public Policy", and "Managing for Environmental Sustainability". The Environmental Technology group currently includes courses in "Resource Reduction", "Product Stewardship", "Industrial Waste Water Management", "Air Emissions", and "Solid and Hazardous Waste Management". Both of these lists are expected to grow as the new graduate programs gain visibility and academic departments expand their portfolios to include appropriate courses.

\subsection{Sustainable Engineering Seminar Series}

The seminar series is intended to expose the students to a variety of topics and speakers that are both current and relevant to the field. A graduate seminar series currently exists in each of the host departments (Industrial and Systems Engineering and Mechanical Engineering). The idea is for the SE Seminar Series to be offered as a subset of the existing series and jointly for both departments.

\subsection{Capstone Project or Thesis}

For each program there is a required summary capstone experience. For the Applications of Sustainable Engineering capstone project (for M.Eng. students, 4 credit hours), students are expected to develop a design or an implementation with applications in sustainability. Comprehensive assessments of such developments are anticipated. In the thesis (for M.S. students, 9 credit hours), students are expected to engage in a novel research problem. A formal written thesis and oral defense before a faculty committee are required.

\section{Summary}

At the KGCOE, student interest has motivated a number of developments with respect to the discipline of sustainable engineering. These developments include

- expanded course offerings with sustainability themes

- a richer selection of sustainability oriented multidisciplinary senior design experiences

- the founding of a chapter of Engineers for a Sustainable World at RIT

- the establishment of an undergraduate minor program in Sustainable Product Development

- the creation of two Master's degree programs in Sustainable Engineering

These initiatives have been true grass-roots efforts motivated by student and faculty interest. This presents a sharp contrast from the top-down approach often taken by administration when developing curricula. The positive reinforcement loop that has taken place in engineering at RIT should be noted: early efforts attracted increased student and faculty interest, which in turn led to further effort and development of sustainability themed curricula. 
Bibliographic Information

[1] Accreditation Board for Engineering and Technology (2005); Criteria for Accrediting Engineering Programs. Document E1 EAC Criteria; http://www.abet.org/pev.shtml; accessed October 9, 2006.

[2] Canfield, E. (2005). Exergetic Based Leak Detection and Diagnosis Methodology for Automotive Carbon Dioxide Air Conditioning Systems. Master Thesis, Department of Mechanical Engineering. Rochester Institute of Technology.

[3] Center for Sustainable Engineering (2008); http://www.csengin.org/; accessed February 21, 2008.

[4] Daccarett, J. Modeling Environmental Impact of Demand Variability upon Supply Chains in the beverage Industry (working paper)

[5] George, E. (2006). Exergetic Analysis of Energy Intensive Systems within Buildings. Master Thesis, Department of Mechanical Engineering. Rochester Institute of Technology.

[6] Gillis, B. (2005). Large Scale Proactive Approach to Reducing Energy Consumption of City Buildings in Rochester. Master Thesis, Rochester Institute of Technology.

[7] Hurst, K. (2006). Making Sustainable and Environmental Improvements through Focused Factories. Master Thesis, Department of Industrial and Systems Engineering. Rochester Institute of Technology.

[8] Mariano, M. (2005). Remanufacturing Alternatives to Reduce the Magnitude of Environmental Impacts Using TRACI. Master Thesis, Department of Industrial and Systems Engineering. Rochester Institute of Technology.

[9] National Academy of Sciences (1997). Preparing for the $21^{\text {st }}$ Century: The Education Imperative. Washington DC: National Academy Press.

[10] National Research Council (2003). Evaluating and Improving Undergraduate Teaching in Science, Technology, Engineering, and Mathematics. Committee on Recognizing, Evaluating, Regarding, and Developing Excellence in Teaching of Undergraduate Science, Mathematics, Engineering and Technology. Washington DC: National Academy Press.

[11] National Research Council (1999). Transforming Undergraduate Education in Science, Mathematics, Engineering, and Technology. Committee on Undergraduate Science Education, Center for Science, Mathematics and Engineering Education, Washington DC: National Academy Press.

[12] Sciortino, J. (1999). Using Product Architecture to Maximize Environmental Performance. Master Thesis, Department of Industrial and Systems Engineering. Rochester Institute of Technology.

[13] United Nations World Commission on Environment and Development (1987). Our Common Future. Oxford University Press.

[14] Wood, C. (2007). Economic and Environmental Impacts of Waste Cooking Oil Collection for Use as Biodiesel. Department of Industrial and Systems Engineering. Rochester Institute of Technology.

[15] Wuotinen, J. (2003). Utilization of Statistical Tools to Identify Assignable Causes of Variability and Model Performance of a Wet Electrostatic Precipitator (WESP). . Department of Industrial and Systems Engineering. Rochester Institute of Technology. 


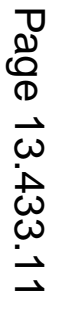

$$
\text { 二 }
$$

